NBER WORKING PAPER SERIES

IS LEISURE A NORMAL GOOD? EVIDENCE FROM THE EUROPEAN PARLIAMENT

\author{
Naci H. Mocan \\ Duha Tore Altindag \\ Working Paper 17329 \\ http://www.nber.org/papers/w17329
}
NATIONAL BUREAU OF ECONOMIC RESEARCH
1050 Massachusetts Avenue
Cambridge, MA 02138
August 2011

We thank Kaj Gittings for helpful comments, and Ana Ichim and Natalia Boliari for providing information on Romanian and Bulgarian elections, respectively. The views expressed herein are those of the authors and do not necessarily reflect the views of the National Bureau of Economic Research.

NBER working papers are circulated for discussion and comment purposes. They have not been peerreviewed or been subject to the review by the NBER Board of Directors that accompanies official NBER publications.

(C) 2011 by Naci H. Mocan and Duha Tore Altindag. All rights reserved. Short sections of text, not to exceed two paragraphs, may be quoted without explicit permission provided that full credit, including (C) notice, is given to the source. 
Is Leisure a Normal Good? Evidence from the European Parliament

Naci H. Mocan and Duha Tore Altindag

NBER Working Paper No. 17329

August 2011

JEL No. J22,J33,J4

\begin{abstract}
Prior to July 2009, salaries of the members of the European Parliament were paid by their home country and there were substantial salary differences between parliamentarians representing different EU countries. Starting in July 2009, the salary of each member of the Parliament is pegged to $38.5 \%$ of a European Court judge's salary, paid by the EU. This created an exogenous change in salaries, the magnitude and direction of which varied substantially between parliamentarians. Parliamentarians receive per diem compensation for each plenary session they attend, but salaries constitute unearned income as they are independent of attendance to the Parliament. Using detailed information on each parliamentarian of the European Parliament between 2004 and 2011 we show that an increase in salaries reduces attendance to plenary sessions and an increase in per diem compensation increases it. We also show that corruption in home country has a negative effect on attendance for seasoned members of the Parliament.
\end{abstract}

Naci H. Mocan

Department of Economics

Louisiana State University

2119 Patrick F. Taylor Hall

Baton Rouge, LA 70803-6306

and NBER

mocan@1su.edu

Duha Tore Altindag

Auburn University

Department of Economics

0334 Haley Center

Auburn AL, 36849

altindag@auburn.edu 


\section{Is Leisure a Normal Good? Evidence from the European Parliament}

\section{Introduction}

The impact of income on labor supply is a key piece of information in the analysis of the determinants of working hours and it plays a significant role in a variety of settings, including tax and welfare policy. ${ }^{1}$ There is, however, substantial variation in the magnitude of the income elasticity of labor supply reported in the literature. Pencavel (1986) summarizes the research published in the 1970s and shows that the estimates of the marginal propensity to earn are in the range of -0.70 to +0.08 , where positive estimates suggest that labor supply goes up as income rises and they therefore violate the assumption that leisure is a normal good (Pencavel 1986; Tables 1.19 and 1.21). ${ }^{2}$ A more recent survey similarly reports income elasticity estimates in the range of -0.40 to +0.52 (Blundell and MaCurdy 1999).

One of the primary reasons for such a discrepancy in income elasticity estimates is the difficulty in the measurement of nonwage income and the struggle to find truly exogenous movements in nonwage income. A limited number of papers were able to provide reliable estimates of income elasticity of labor supply by exploiting exogenous increases in income that emerged in narrow settings. For example, Holtz-Eakin, Joulfaian and Rosen (1993) analyzed the labor force participation behavior of individuals who received inheritance and reported an

\footnotetext{
${ }^{1}$ For example, if government revenue generated by higher taxes is spent on transfers, it is important to determine the proper magnitude of income-compensated wage elasticity of labor supply to determine the impact of taxes on labor supply and hours worked (Alesina, Glaeser and Sacerdote 2005). To make an inference on the magnitude of compensated wage elasticity, one needs both the uncompensated wage elasticity and income elasticity.

${ }^{2}$ The Slutsky equation decomposes the impact of a wage $(w)$ increase in substitution and income effects as $\partial h / \partial w=s+h(\partial h / \partial y)$, where $h$ is hours worked, $s$ stands for the substitution effect, and $y$ represents nonwage income. Multiplying the Slutsky equation by $w / h$ gives $\mathrm{E}=\mathrm{E}^{*}+w(\partial h / \partial y)$, where the uncompensated elasticity of labor supply with respect to wage is $\mathrm{E}=(\partial h / \partial w)(w / h), \mathrm{E}^{*}$ is incomecompensated elasticity of labor supply, and $w(\partial h / \partial y)$ is termed marginal propensity to earn by Pencavel.
} 
implied unearned income elasticity of -0.03 . Joulfaian and Wilhelm (1994) used PSID data and found that the impact of inheritance receipt on labor supply was almost zero. Imbens, Rubin, and Sacerdote (2001) employed data on lottery winners in Massachusetts in the mid-1980s to investigate the impact of lottery prizes on labor market earnings. The estimated marginal propensity to earn was about $-0.11 .^{3}$

In this paper we provide an estimate of the income elasticity of labor supply using data on the members of the European Parliament. There are advantages of analyzing this group of individuals. First, the structure of compensation pertaining to the members of the European Parliament includes the main ingredients of textbook labor supply analysis. Each member of the Parliament receives a per diem compensation for every parliamentary session he/she attends. This per diem compensation, which is $€ 304$ currently (about $\$ 438$ at the current exchange rate), is not intended to cover travel expenses because travel expenses that are related to attendance in parliamentary sessions are reimbursed separately by the European Parliament. Thus, per diem compensation is the daily wage for the parliamentarians. Each member of the Parliament also receives a fixed salary, which does not depend on the number of sessions attended. Put differently, the salary is independent of the work effort and the attendance record of the parliamentarian, and therefore it effectively constitutes unearned income.

Much of the labor supply literature has grappled with serious measurement problems in wages, hours, and nonwage income. This is not the case here because the daily wage rate (per diem compensation), labor supply (the number of sessions attended) and nonwage income (salary) are recorded with precision by the European Parliament, and are therefore not subject to

\footnotetext{
${ }^{3}$ Of course, a trade-off exists between obtaining unbiased estimates of income elasticity by exploiting exogenous increases in unearned income in specific populations such as lottery winners and inheritance recipients, and the external validity of the results. This point is relevant for this paper as well.
} 
measurement error. More importantly, we exploit an exogenous change in nonwage income due to an alteration in the salary structure of the European Parliament, implemented in 2009, which allows us to identify the income elasticity of labor supply. Prior to 2009, members of the European Parliament received salaries which were determined by their home country. As a result, there was substantial variation in salaries between members representing different countries. For example, the salary of a member from Poland was $€ 29,209$, whereas the salary of a member from Italy was $€ 142,146$. Starting with the $7^{\text {th }}$ Term in the Summer of 2009 , the salaries were equalized between the Members of the Parliament to $€ 91,983$ (about $\$ 132,500$ ), and then were increased slightly in each subsequent year. This created an exogenous change in unearned income, the magnitude and direction of which varied substantially between parliamentarians.

We compiled the attendance record (by plenary session) of each member of the European Parliament during the sixth and the seventh parliamentary terms of the European Parliament (from 2004 to 2011). Merging this information with personal characteristics of the members obtained from their CVs and the information on their salaries and per diem compensation, produced a panel data set that spans 2004-2011. We find that an increase in unearned income (salaries) of the parliamentarians reduces the number of plenary sessions attended, although the estimated elasticity is small. An increase in daily wages (per diem compensation) increases labor supply. We also find that members of the EU parliament from countries with higher levels of corruption have a tendency to attend fewer sessions and that this effect is concentrated among seasoned members of the Parliament. 
The rest of the paper is organized as follows: Section II presents background information on the European Parliament. In sections III we describe the empirical framework. Section IV presents the data. Section V describes the results and VI is the conclusion.

\section{The Structure of the European Union Parliament}

The European Parliament is the elected legislative body of the European Union (EU). The elections of the European Parliament are held every five years by voters in each of the 27 member countries of the EU. The most recent elections were held in the Summer of 2009 for the seventh parliamentary term. Because of proportional representation, countries with bigger populations seat more parliamentarians. Currently, the number of seats ranges from five (Malta) to 99 (Germany) in a total of 736 seats.

Members of the Parliament convene both in Brussels and Strasbourg for plenary sessions. ${ }^{4}$ Some members of the Parliament live in their home country rather than in Brussels, and their travel expenses are paid by the Parliament. The parliamentarians also receive allowances for their expenses related to costs of running their offices. Furthermore, each parliamentarian receives a per diem compensation for each day they attend the parliamentary sessions. This per diem pay was $€ 262$ in 2004 , and it went up to $€ 304$ in 2011 (about \$438).

Until the seventh Parliamentary term, the salary of each member was pegged to the salary of a parliamentarian in their home country. For example, the salary of a European Parliamentarian from Spain was the same as the salary of the members of the Spanish Parliament in Madrid, and the salary of an EU parliamentarian representing Austria was equal to the salary of the member of the Austrian parliament in Vienna. A new statute for the European Parliament, enacted on June 23, 2005, equalized the salaries of the Members of the EU

\footnotetext{
${ }^{4}$ In Brussels they also attend meetings of the parliamentary committees and political groups.
} 
Parliament. More specifically, each parliamentarian's salary is now equivalent to 38.5 percent of a European Court judge's salary, paid out of the EU budget. This new salary structure became effective in the seventh term of the Parliament, in Summer 2009. This amount is currently $€ 95,483$.

Table 1 displays information about the 14 parliamentary periods that will be used in this paper. Periods 1-10 pertain to the sixth parliamentary term spanning July 2004 to June 2009. Each year consists of two terms: the first term covers the period from September 1 to December 31, while the second one covers January 1 to August 31. The duration of the terms right before and right after an election is slightly different because they are disrupted by elections (periods 1 , 10 and 11). Table 1 also displays the number of plenary sessions that took place in each period. For example, in 2008 there were a total of 63 plenary sessions $(39+24)$. A member of the parliament who attended all of these 63 plenary sessions would have earned $€ 18,081$ in per diem allowance, in addition to the fixed base salary. This means, for example, that a member of the Parliament from Slovakia would have doubled his/her income by attending all sessions (the salary received by Slovakian members was $€ 18,000$ in 2008). A Parliamentarian from Spain would have increased his/her income by 41 percent, and the income of a member from Finland would have increased by 26 percent.

As of June 6, 2011, which was the last day of data collection for this paper, 25 plenary sessions were held in the $14^{\text {th }}$ Period. This period, which started on January 1,2011 has adjourned on July 7, and there were nine more plenary sessions between June 6 and July 7 . This means that the number of sessions attended is underreported in the data for this last period. However, dropping this last period from the analysis did not alter the results. 
Table 2 displays the number of Parliamentarians from each EU country in June 2009 (at the end of the sixth Parliament), the share of that country in total seats in the EU Parliament, and their average salaries during the sixth term, from July 2004 to June 2009. ${ }^{5}$ There is substantial variation in salaries. The highest salary in the EU Parliament was $€ 142,146$ paid by the Italian government to the Italian Members of the EU Parliament. Bulgarians received the lowest salary of $€ 10,226$.

As mentioned earlier, starting with the seventh parliamentary term in July 2009, each member's salary was set to $€ 91,983$, regardless of the country of representation. Figure 1 displays this information, where the dashed line is the average real salary (nominal salaries deflated by the EU price index) of those members of the European Parliament (weighted by the number of the seats), whose salaries were greater than the unified post-2009 salary. This group consists of the members of the Parliament from Italy, Ireland and Austria. The solid line before 2009 shows the weighted average real salaries of the parliamentarians from the remaining 24 countries whose salaries were below that of the post-2009 salary.

Figure 2 displays the difference in salaries between the two groups of parliamentarians. More specifically, the heavy line in Figure 2 is the difference in average salaries between the Italian, Irish and Austrian members of the Parliament, and those of the second group, consisting of all other members. This salary difference (measured on the right-hand scale) was about $€ 70,000$ between 2004 and 2009, and it became zero in the seventh parliamentary term after the European Parliament decided that each member would be paid the same salary. The key variable of the analysis is the labor supply (plenary sessions attended) of the members of the Parliament. This variable is based on official attendance records. Figure 2 also displays the difference in average attendance rate between the two groups. Between 2004 and 2009, the

\footnotetext{
${ }^{5}$ Romania and Bulgaria became members on January 1, 2007.
} 
attendance rate of the first group (high earners) was about five percentage points lower than that of the second group (low earners). With the start of the seventh parliamentary term, where the salaries of the members in the first group declined and the salaries of the members in the second group increased, the difference in the attendance rates went down to about zero. Our empirical analysis will not be based on a difference-in-differences framework; nevertheless Figure 2 is informative as it suggests that hours of work of those who faced a decline in their unearned income went up in comparison to those who faced an increase in their unearned income.

\section{Empirical Specification}

The empirical counterpart of a standard static labor supply equation can be described as: Attendance $_{\text {ict }}=\alpha+\beta$ Salary $_{i c t}+\gamma$ Wage $_{\text {ict }}+\mathbf{X}_{\text {ict }} \Omega+\mathbf{C}_{\mathrm{ct}} \Psi+\tau_{\mathbf{t}}+\lambda+\varepsilon_{\text {ict }}$

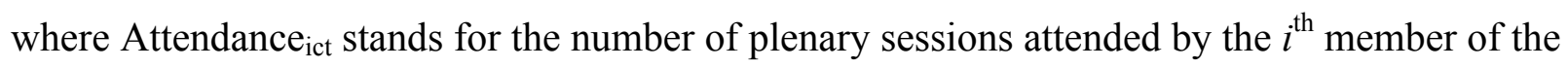
European Parliament who represents country $c$, in period $t$. Salaryict represents the salary of the

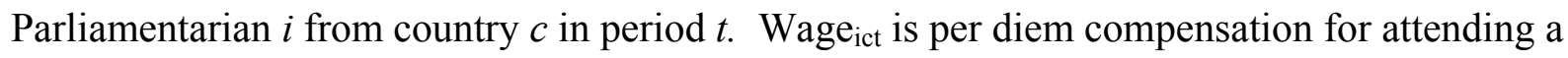
session. Salary and Wage are deflated by the EU price index. The vector X includes personal characteristics such as gender, age, education and tenure in the Parliament. It also includes the average attendance record of other Parliamentarians in $i$ 's political group as explained below. $\mathbf{C}_{\mathrm{ct}}$ includes measures of per capita income and the extent of corruption in the home country to capture socio-economic attributes of the country of origin of the Parliamentarian. These variables gauge different dimensions of economic development which may impact hours worked. $\lambda$ represents a time trend, $\tau_{\mathrm{t}}$ stands for period effects, and $\varepsilon_{\text {ict }}$ is an error term. The time trend controls for a potential secular trend in attendance. Period effects are controlled for to account

for the fact the Fall period (September-December) is shorter than the Winter-Spring period, and 
for the possibility that some periods require heavier legislative action than other due to idiosyncratic political circumstances. Robust standard errors are clustered at the parliamentarian level. We also estimate specifications which include Parliamentarian fixed-effects, instead of personal attributes.

To make use of the exogenous variation in the salaries of parliamentarians, we focus on parliamentarians who served in the sixth parliament (where the salaries were paid by their home country) and who also served in the seventh Parliament (where the salaries are paid by the EU). These parliamentarians faced an exogenous change in their salaries between the sixth and the seventh terms. This strategy involves the evaluation of the differences in parliamentarians' attendance records before and after the change in the salary structure. We expect a negative relationship between Salary and Attendance. In other words, those individuals who experienced a raise are expected to attend fewer parliamentary sessions than they did before the raise. Similarly, those parliamentarians who experienced a pay cut are expected to attend more sessions. Although salary in this context constitutes unearned income for the members of the parliament, they may have other types of unearned income, from other sources, as well. We assume that variations in the European Parliament salary are uncorrelated with other components of their total unearned income.

The labor supply of the parliamentarians who served both in the sixth and the seventh parliamentary terms may have declined during the seventh term, not because of the increase in salary but because of aging or because they are more seasoned in the seventh term and therefore feel less pressure to attend the sessions. We include controls for age and tenure to capture the impact of a potential change in "tastes for work". However, to address this potential issue, we also estimate the model using the sample of freshman and the sample of seasoned 
parliamentarians. We define freshman parliamentarians as those who have never been elected before, and seasoned parliamentarians as those who had been elected at least once before. We compare the attendance record of freshmen of the sixth Parliament (2004-2009) to that of those who entered the seventh Parliament in 2009 as freshmen. The former group faced a different salary structure than the latter one. The same strategy is applied to the sample of seasoned parliamentarians, where we compare seasoned parliamentarians who faced the new salary regime in the seventh Parliament to seasoned parliamentarians from the same country who faced a different salary in the sixth Parliament. If characteristics that may affect the attendance of the parliamentarians are controlled for, the comparison of the number of sessions attended by the freshman and seasoned parliamentarians before and after the change in the salary structure identifies the impact of salary on attendance.

It can be argued that the composition of the re-elected parliamentarians for the seventh parliamentary term may depend on the change in salaries. Specifically, the increase in salaries between the sixth and the seventh terms could have attracted a certain breed of individuals to the EU Parliament whose aim was to earn high salaries but not work hard. However, we show that the re-election propensity is not related to the extent of the increase/decrease in salaries, suggesting that the probability of being re-elected is about the same in a country regardless of whether the parliamentarians received a pay raise or a pay cut. Nevertheless, we entertain the hypothesis that the change in the salary structure has attracted shirkers to the seventh Parliament. We identify such potential shirkers as explained below. The estimated income elasticity among this group is not different from that obtained by using the entire sample, indicating that the results are not driven by self-selection of certain type of individuals to the parliament following the increase in salaries. 


\section{Data}

Individual level data on parliamentarians are obtained from the website

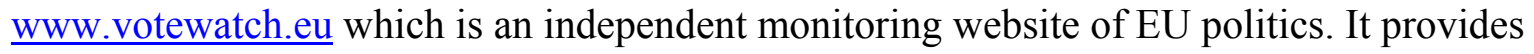
detailed information about the members of the European Parliament regarding their activities in the parliament as well as their personal characteristics. Votewatch.eu employs the European Parliament's attendance, voting and activity data, which is available through the Parliament's website, and organizes them to make it available to the general public. The website covers the activities of the Parliamentarians during the entire sixth and seventh parliamentary terms, between 2004 and 2011.

The attendance records of the parliamentarians are provided as the proportion of the sessions each member has attended in each period. Periods are defined in Table 1. For example, the first period starts on July 20, 2004 (the first day of sixth parliamentary term) and continues until December 31, 2004. Because we know the number of plenary sessions in each period, multiplying the official attendance rate for each period by the number of plenary sessions in that period generates the number of sessions attended by each member. ${ }^{6}$

Salaries of the members of the EU Parliament were set to €91,983 in July 2009 as described earlier. They were increased to €93,686 in January 2010, and to €95,482 in January 2011. 'Before July 2009, Parliamentarians' salaries were determined by their country of origin. The salary information prior to this date is obtained from two sources. The information

\footnotetext{
${ }^{6}$ For example, if a particular Member of the Parliament has a reported attendance rate of 80 percent in Period 1 (July 20, 2004 - December 31, 2004), given that there were 24 plenary sessions during that period, we calculate that this particular Parliamentarian has attended 19 sessions during this period.

${ }^{7}$ Salary information is obtained from Francisco José Estela Burriel, head of the Members' Travel and Subsistence Expenses Unit of the European Parliament.
} 
pertaining to 2004 is obtained from the EU information website of Folketing (the National Parliament of Denmark). ${ }^{8}$ For the years 2005-2009, we used the information provided by the UK Office of the European Parliament's Directorate General for Communication. Because parliamentarian salaries were not available for all countries and all years, we assigned to each parliamentarian the average of that country's parliamentarian salary in the years before $2009 .{ }^{9}$ This is not problematic because the existing salary data show that salaries do not change appreciably between 2004 and 2009 in any country.

Other individual level variables are constructed using information provided by the www.votewatch.eu. Specifically, we went to the web segment of each EU Parliamentarian to identify their gender, and to obtain information on the date of birth, which is used to calculate age. ${ }^{10}$ The web site also contains short CVs of the Parliamentarians. Using the information on their CVs, we created a dummy variable, $\mathrm{PhD}-\mathrm{MD}$, which takes the value of one if the member of the Parliament has a PhD or an MD degree. The variable titled Political Group Attendance measures the average attendance of other members of the Parliamentarian's political group. ${ }^{11}$ This variable is intended to capture the extent of involvement of the member's political group in

\footnotetext{
${ }^{8}$ http://www.eu-oplysningen.dk/euo_en/spsv/all/32/

${ }^{9}$ Country-specific salary information is obtained from Michelle Kneeshaw of the UK Office of the European Parliament's Directorate General for Communication, who provided us with three fact sheets on the salaries of the members of national parliaments in the EU. The fact sheets dated July 1, 2005, November 8, 2007, and April 14, 2009 display the salaries of the members of the national parliaments in $2005,2006 / 2007$, and 2007/2008/2009, respectively.

${ }^{10}$ In a few cases, the web site does not contain a picture of the member of the Parliament. In those cases, we tried to identify gender by the first name.

${ }^{11}$ Parliamentarians are grouped by political affiliation and not by nationality. There are currently seven political groups in the European Parliament. Parliamentarians may not belong to more than one political group but some do not belong to any political group.
} 
the legislative process. ${ }^{12}$ We also created seven indicator variables to identify whether the individual was a member of any of the seven European parliamentary terms. ${ }^{13}$ Indicator variables $1^{\text {st }}$ Parliament, $2^{\text {nd }}$ Parliament, and so on identify whether an individual has served in the $1^{\text {st }}$ Parliament, $2^{\text {nd }}$ parliament and so on, respectively.

Table $3 \mathrm{~A}$ reports the descriptive statistics. The four columns pertain to four different samples that are used in various specifications. Column (1) includes the main sample, which consists of the members of the European Parliament who were elected to the $6^{\text {th }}$ and/or $7^{\text {th }}$ Parliament. ${ }^{14}$ Average attendance per Plenary Session is 25 days, and average salary is $€ 76,700$ Average per diem pay is 285 Euros. Tenure in the $6^{\text {th }}$ or $7^{\text {th }}$ Parliament is intended to capture the extent of the experience of the parliamentarian. This variable measures the cumulative number of periods attended. For example, the value of this variable for a member who attended at least one plenary session in all periods of the sixth term would be 1 in period 1 and 10 in period 10 (see Table 1). For a member, who was part of the sixth parliamentary term and who is re-elected for the seventh term, and who attended at least one session in each period, this variable

\footnotetext{
${ }^{12}$ There are currently 7 political groups in the EU Parliament: European People's Party (EPP), Progressive Alliance of Socialists and Democrats (S\&D), Alliance of Liberals and Democrats for Europe (ALDE), European Conservatives and Reformists (ECR), The Greens-European Free Alliance (Greens-EFA), European United Left-Nordic Green Left (GUE-NGL), Europe of Freedom and Democracy (EFD). In addition, some Members of the Parliament do not belong to any political groups. These Members are referred to as Non-Inscrits (NI). ECR group is recently formed with the beginning of the $7^{\text {th }}$ parliament. Two political groups from the $6^{\text {th }}$ parliament, Independence/Democracy (IND/DEM) and Union for Europe of the Nations (UEN) merged to form EFD in the $7^{\text {th }}$ parliament. The political group European People's Party-European Democrats (EPP-ED) in the $6^{\text {th }}$ parliament is divided into two political parties in the $7^{\text {th }}$ parliament, EPP and ECR.

13 The first EU Parliamentary term spanned the years 1979 to 1984, and there is one person in the seventh Parliament who was a member of all seven parliamentary terms, thus serving continuously from 1979 to 2011. We obtained the information about whether a member of the 6th or 7th Parliament was also a parliamentarian in the previous terms from the data set used by Hix, Noury and Gerard (2006).

${ }^{14}$ At the end of the $6^{\text {th }}$ Parliament, in the Summer of 2009, there were 776 Members in the European Parliament.
} 
would take the value of 14. A person who is elected for the seventh term but who was not part of then the sixth term, would have a value of 4 for this variable in period 14 .

Table 3B displays the summary statistics for member attributes, using each member as a unit of observation. There are 1,151 unique members of the parliament in the data set who were part of the sixth and/or the seventh Parliament. Thirty-two percent of the members are female, and 22 percent have a $\mathrm{PhD}$ or MD degree. The average age is 50 . The mean value of the dichotomous variable Member in the $1^{\text {st }}$ Term is 0.01 in column (1). This means that one percent of the 1,151 members (12 people) served in the first parliamentary term (1979 to 1984).

Column (2) of Table 3A displays the descriptive statistics of those Parliamentarians who served in the sixth parliamentary term and were re-elected for the seventh term. This group consists of 361 people. Note that these individuals were exposed to the exogenous change in salaries that was implemented at the beginning of the seventh Parliament. Of the 361 re-elected members, 36 are Austrians, Irish or Italians. These members faced a decrease in their salaries between the sixth and the seventh terms. The remaining 325 members of the re-elected group faced an increase in their salaries.

Column (3) of Table 3A presents descriptive statistic pertaining to freshman members in the sample. Put differently, these statistics pertain to the freshman years of the Parliamentarians. Note again that our data set spans the sixth and the seventh Parliaments (see Table 1). Therefore, if a member is elected to the sixth Parliament as a freshman and re-elected to the seventh Parliament, then his/her information (attendance, salary, etc.) during the sixth Parliament is included in this sample. Similarly, this sample contains information on those individuals who are elected to the European Parliament first time for the seventh term. 
Finally, column (4) of Table 3A displays descriptive statistics on seasoned member-

sessions. A seasoned member is defined as somebody have has served at least one prior term in the European Parliament. For example, if a member has served in the sixth and the seventh Parliaments, data summarized in column (4) contain information about this person in his/her seventh term. As another example, if a member has served in the third, sixth and seventh Parliaments, column (4) contains data on this member's activity during the sixth and seventh Parliaments. ${ }^{15}$

Real GDP per capita is obtained from World Bank's World Development Indicators database. ${ }^{16,17}$ The corruption variable is constructed using Transparency International's Corruption Perceptions Index (CoPI) ${ }^{18}$ For each year between 2004 and 2010, we ranked the countries according to the CoPI and determined the percentile ranking of each country, where a higher percentile indicates a higher level corruption in the world corruption distribution in that year. Because the CoPI is not available in 2011, we assigned the same values to each country as in 2010, which assumes that their world-wide ranking remains the same during that year. ${ }^{19}$

${ }^{15}$ Note that attendance data are only available for the $6^{\text {th }}$ and the $7^{\text {th }}$ parliaments. Therefore, our data are restricted to these terms (2004-2011). However, we have information on whether any member has served in previous Parliaments. Therefore, we can identify whether Parliamentarians in our sample have served in prior terms.

${ }_{16}^{16} \mathrm{http}$ ://data.worldbank.org/indicator

17 GDP per capita is not available for 2010 and 2011, therefore it is extrapolated linearly.

18 See Mocan (2008) and Mocan (2009) for analysis on objective and subjective measures of corruption.

19 TI's CPI ranges from 0 (most corrupt) to 10 (least corrupt). We obtained the CPI for each country pertaining to the years 2004 to 2010 (the last year available). We reversed the CPI scale so that higher values represent more corruption. The countries in the TI data are Albania, Algeria, Angola, Argentina, Armenia, Australia, Austria, Azerbaijan, Bahrain, Bangladesh, Barbados, Belarus, Belgium, Benin, Bolivia, Bosnia and Herzegovina, Botswana, Brazil, Bulgaria, Cameroon, Canada, Chad, Chile, China, Colombia, Costa Rica, Croatia, Cuba, Cyprus, Czech Republic, Denmark, Dominican Republic, Ecuador, Egypt, El Salvador, Eritrea, Estonia, Ethiopia, Finland, France, Gabon, Gambia, Georgia, Germany, Ghana, Greece, Guatemala, Haiti, Honduras, Hong Kong, Hungary, Iceland, India, Indonesia, Iran, Iraq, Ireland, Israel, Italy, Jamaica, Japan, Jordan, Kazakhstan, Kenya, Kuwait, Kyrgyzstan, Latvia, Lebanon, Libya, Lithuania, Luxembourg, Madagascar, Malawi, Malaysia, Mali, Malta, Mauritius, Mexico, Moldova, Mongolia, Morocco, Mozambique, Myanmar, Namibia, Nepal, Netherlands, New Zealand, Nicaragua, Niger, Nigeria, Norway, Oman, Pakistan, Panama, Papua New Guinea, Paraguay, Peru, 
Table 3B shows that the average value of Corruption pertaining to the countries in the EU is 21 , indicating the $21^{\text {st }}$ percentile on the World corruption distribution. In 2010, Iraq and Myanmar are ranked as the most corrupt countries (the $99^{\text {th }}$ and $100^{\text {th }}$ percentiles on the World corruption distribution, respectively); Denmark is the least corrupt country. Germany is in the $12^{\text {th }}$ percentile, Spain is in the $21^{\text {st }}$ percentile, Bulgaria and Italy are is in the $44^{\text {th }}$ percentile and Greece is ranked in the $51^{\text {st }}$ percentile.

\section{Results}

\section{Whole Sample}

Columns (1) and (2) of Table 4 present the results that employ the entire sample, consisting of all Parliamentarians who participated in the sixth and/or the seventh Parliaments. All regressions in all tables include 13 dummy variables for period effects and a time trend. Column (1) reports result from the model that includes parliamentarian fixed effects and column (2) presents the estimates obtained from the specification that includes personal attributes of the parliamentarians.

The coefficient of Salary is negative and highly significant, indicating that an increase in salary (unearned income in this context) generates a decline in the number of plenary sessions attended. The coefficients in columns (1) and (2) imply an income elasticity of -0.04 to -0.08 . This estimate is similar in magnitude to those obtained from inheritance recipients and lottery winners. Per diem pay, which is the daily wage, has a positive impact on attendance. The

Philippines, Poland, Portugal, Qatar, Romania, Russia, Saudi Arabia, Senegal, Serbia, Seychelles, Sierra Leone, Singapore, Slovakia, Slovenia, South Africa, Spain, Sri Lanka, Sudan, Sweden, Switzerland, Syria, Taiwan, Tajikistan, Tanzania, Thailand, Trinidad and Tobago, Tunisia, Turkey, Turkmenistan, Uganda, Ukraine, United Arab Emirates, United Kingdom, Uruguay, Uzbekistan, Venezuela, Vietnam, Yemen, Zambia, Zimbabwe. 
implied uncompensated wage elasticity is in the range of 0.95 to 1.06 , which is consistent with estimates reported by previous research that used European data. ${ }^{20}$

Peer pressure seems to have an effect on attendance behavior. If there is a 10 percentage point increase in the sessions attended by the colleagues of the Parliamentarian who belong to the same political group, he/she attends one more session during a plenary session period. ${ }^{21}$ Age has a small non-linear impact on attendance. In the specification reported by column (2), attendance peaks at age 59 .

There is little variation in per capita income and corruption within a country from year to year. This makes is difficult to estimate the coefficients with precision. Nevertheless, the coefficient of corruption is estimated reasonably precisely. The results indicate that members of the European Parliament who represent more corrupt countries have a tendency to attend fewer sessions. Fisman and Miguel (2007) analyzed United Nations diplomats in New York City. They found that diplomats from high-corruption counties violate parking regulations (at zero cost to themselves because of diplomatic immunity) more frequently than diplomats from lowcorruption counties. Our result is similar in essence to those reported by Fisman and Miguel as it suggests that exposure to corruption may impact individual behavior.

\footnotetext{
${ }^{20}$ For example, Arellano and Meghir (1992) use British family Expenditure Survey and British Labor Force Survey and report uncompensated wage elasticity as high as 0.71. Colombino and Del Boca (1990) report estimates in the range of 0.66 to 1.18 using Italian data. van Soest et al. (1990) use Dutch data and estimate an uncompensated wage elasticity of 0.79; Blomquist and Hansson-Brusewitz (199) report an estimate of about 0.8 using Swedish data. Arrufat and Zabalza (1986) use the British general Household Survey and report and estimate of 2.03 .

${ }^{21}$ A causal interpretation is difficult here because the political groups are being formed endogenously. Although political views are arguably the most significant determinants of group formation, proclivity towards shirking could be one aspect of self-selection into groups.
} 


\section{Re-elected Parliamentarians}

Columns (1) and (2) of Table 4 report the results from the pooled sample which includes all members of the European Parliament in the sixth and the seventh terms. Columns (3) and (4) report the results that employ data on the parliamentarians who are observed both before and after the change in the salary structure. There are 361 such members in our sample (who were served in the sixth term and were re-elected and served for the seventh term). This analysis involves a comparison of the attendance of the same parliamentarians before and after the change in the salary structure. The results are presented in columns (3) and (4) of Table 4. They are very similar to the ones obtained from the whole sample.

The specification that uses the re-elected parliamentarians identifies the income elasticity through the exogenous change in salaries faced by these individuals. The salary increase, however, was implemented between the sixth and the seventh parliamentary sessions. Therefore, it is possible that those re-elected parliamentarians had a strong desire to enjoy the higher salaries that would be forthcoming in the seventh term. Conversely, the Italian, Irish and Austrian members who served in the sixth term were expecting a salary decline with the start of the seventh term. This could have curtailed their desire to run for re-election. This argument suggests that the upcoming salary increase/decrease may have altered the willingness and the propensity to re-enter the seventh Parliament. The data do not support this hypothesis. Figure 3 displays the re-election rates among the incumbent parliamentarians of the sixth Parliament (the proportion that is re-elected to the seventh Parliament) in each country as a function of the change in salary between the two terms. The solid line shows the fitted values from a regression of the former on the latter. No clear pattern emerges. The highest salary increase was enjoyed by Bulgarians with an increase of more than $800 \%$ (from $€ 10,226$ to $€ 91,983$ ). Yet, the re-election 
rate among the Bulgarian members of the European parliament was a moderate 53 percent. Members of the European Parliament from the UK had a higher re-election rate (71 percent), although the salary increase they faced between the sixth and the seventh parliaments was only 11 percent. Parliamentarians from Malta, Slovakia and Latvia had nearly equivalent salary increases ( $460 \%$ to $490 \%$ ) but their re-election rates ranged from 37 percent to 80 percent.

As a complementary analysis we calculated the proportion of re-elected Parliamentarians in each country between the fifth and the sixth Parliaments and compared these rates to the reelection rates between the sixth and the seventh Parliaments. There was no change in the salary structure between the fifth and the sixth Parliaments. Thus, the re-election rates between the fifth and the sixth terms are the product of domestic political processes and the structure of political establishment in each country, and they do not depend of expected EU Parliamentarian compensation. If the new salary structure implemented by the EU has altered the re-election dynamics, the re-election probabilities would be different between the transitions from fifth to sixth and from sixth to the seventh Parliaments.

Figure 4 shows that this is not the case. The re-election rates between the $5^{\text {th }}$ and $6^{\text {th }}$ Parliaments are measured on the horizontal axis and the rates between the $6^{\text {th }}$ and the $7^{\text {th }}$ Parliament are measured vertically. The heavy line represents the 45 -degree. The numbers in parentheses following country names show the percent change in salaries between the $6^{\text {th }}$ and $7^{\text {th }}$ Parliaments. For example, the members of the European Parliament from the UK faced an 11 percent increase in their salaries between the $6^{\text {th }}$ and the $7^{\text {th }}$ Parliaments. Their re-election rate to the $7^{\text {th }}$ term was 72 percent, which was essentially equal to the re-election rate to the $6^{\text {th }}$ term when there was no change in salaries. ${ }^{22}$ Similarly, the re-election rates of Portuguese members

${ }^{22}$ This graph contains only 15 countries because the EU had 15 member countries in the $5^{\text {th }}$ Parliament. (Poland became the $16^{\text {th }}$ member and sent to the Parliament appointed members in May 2004). 
are very similar between the two elections ( $33 \%$ and $38 \%)$, despite the fact that the election for the $7^{\text {th }}$ Parliament was associated with an 87 percent salary increase for the Portuguese members. The same is true for Italians who faced a 34 percent decline in salary when the European Parliament equalized salaries in the seventh Parliament. Yet, the re-election rate of Italians in 2009 is very similar to their re-election rate five years earlier when there was no change in salaries. The biggest drop in the re-election rate took place in Sweden, the members of which faced a 44 percent salary increase, and the second largest drop took place in Ireland, which faced a 2 percent salary decrease. In summary, there is no evidence that the change in the salary structure between the $6^{\text {th }}$ and the $7^{\text {th }}$ Parliaments has altered the re-entry behavior of the incumbents. $^{23}$

\section{Freshman and Seasoned Parliamentarians}

In Table 5 we report the results obtained from two other groups. The first group consists of freshman parliamentarians. These are the individuals who are elected for the very first time to the European Parliament, beginning with the sixth or the seventh term. The idea behind this exercise is to create a sample of individuals who are similar by the virtue of being a novice in the Parliament. Thus, their general attitude towards attendance should be similar.

\footnotetext{
${ }^{23}$ This discussion assumes that the incumbent member of the European Parliament has the advantage in the elections over the challengers. It is also possible that an upcoming salary increase may motivate a large number of challengers to enter the election, which may lower the chances of re-election of the incumbent. Anecdotal evidence suggests that is not the case. For example, in Romania, which experienced a 340 percent jump in salary, the number of candidates went down to 289 in the 2009 elections from 549 candidates in the previous election (http://www.alegeri.tv/ ). In Bulgaria, where the salary increase was the largest, the number of candidates also went down to 215 in 2009 from 218 candidates in the previous election (obtained from the Bulgarian Central Election Committee of the European parliament- Centralna Izbiratelna Komisia Evropeyski Parlament; http://www.cikep2009.eu/?page=244)
} 
The second sample consists of seasoned politicians. They have been members of the European Parliament in previous terms. In this sample of experienced members, we retain observations that belong to parliamentarians who have served at least one previous term in the European Parliament between since its inception in 1979. The results that are obtained from the freshman sample and the seasoned parliamentarian sample are very similar to those reported in Table 4. The impact of country corruption on attendance is not significant in the freshmen sample, but is significant in the sample of seasoned members (column 3) and the coefficient is larger in magnitude in comparison to the one obtained from the whole sample. This suggests that the impact of country corruption on attendance is concentrated on seasoned parliamentarians. For example, a seasoned parliamentarian who represents a country that is ranked in the $50^{\text {th }}$ percentile of world corruption distribution (such as Greece) attends two fewer session per plenary period in comparison to a seasoned parliamentarian who is from a country which has low corruption (such as Ireland, which is on the $10^{\text {th }}$ percentile of the corruption distribution).

The overwhelming majority of the variation in salaries is generated by the change in salaries between the sixth and seventh terms in 2009. Therefore, as an alternative identification strategy, we focused on re-elected parliamentarians who were present both in the sixth and the seventh Parliaments. We calculated the average attendance and the average salary for these parliamentarians within the sixth and the seventh Parliaments, and ran a regression of the change in average attendance between the sixth and the seventh parliaments on the change in mean salary (as well as the changes in other variables) during the same period. This regression is 
based on 361 re-elected parliamentarians. The result, which is reported in column (1) of Table 6, is very similar to ones reported earlier. ${ }^{24}$

Columns (2) and (3) of Table 6 report the results of similar regressions. Here, we use the freshmen sample and the sample of seasoned parliamentarians, respectively. For example, in column (2) we use the sample consisting of the 850 freshmen parliamentarians who were elected for the first time either to the sixth Parliament or the seventh Parliament, and we employ their average attributes (attendance, salary, age, and so on) in the regressions. Column (3) reports the results pertaining to the sample of seasoned parliamentarians. There are 526 unique seasoned

parliamentarians who contribute 662 observations to the model in column (3). ${ }^{25}$ Once again, the results do not change.

Finally, we calculate country averages for both the sixth and the seventh parliaments. Here, countries are the units of observation (there are 27 countries represented in the sixth and the seventh European parliaments). Thus, the dependent variable is the average number of European Parliament sessions attended by the parliamentarians of a given country. The results are very similar to those obtained from previous regressions. Consistent with economic theory, they indicate that an increase in salaries pertaining to the parliamentarians of a given country reduces the number of sessions attended by those parliamentarians.

\section{Robustness}

Notice that after the implementation of the new salary structure in July 2009, there has been only four plenary sessions in the European Parliament until the Summer of 2001, whereas

\footnotetext{
${ }^{24}$ Running the regression in levels and adding individual fixed-effects provided the same results.

25 Some seasoned parliamentarians contribute two observations (for the sixth and for the seventh parliaments) because they were seasoned when they entered the sixth parliament (i.e. they served before the sixth parliament) and they also got re-elected to the seventh parliament.
} 
there were 10 plenary sessions in the sixth Parliament between 2004 and 2009 (see Table 1). We re-estimated all models using the four plenary sessions that took place so far in the seventh Parliament and the first four plenary sessions of the sixth Parliament. The results did not change. In the interest of space we only report one table. Table 7 is the counterpart of Table 5, where the sample consists of the eight plenary sessions described above. Table 7 shows that the results are very similar to those reported in Table 5.

Finally, although there is no evidence that the re-election rates have changed between the sixth and the seventh parliaments as discussed earlier (see figures 3 and 4), we re-visit the postulate that those who are elected to the seventh Parliament in 2009 could be shirkers. Under this scenario, salaries increased and attendance declined in the seventh Parliament because this Parliament has attracted those individuals who have a strong desire to enjoy high salaries and at the same time they have high proclivity for shirking on the job. Call these type-X individuals. If the labor supply of such type-X individuals is highly responsive to income, this could be the reason for estimating a significant relationship between salaries and attendance.

Column (1) of Table 5 has reported the results obtained from the freshmen sample. These are the individuals who are elected for the first time to the sixth or the seventh Parliaments. Freshmen of the sixth Parliament consist of two groups: Those who are re-elected to the seventh Parliament, and those who did not run for re-election, or did not get re-elected. Based on the argument above, dropping the group of not-re-elected freshmen of the sixth Parliament from the sample of all freshmen generates a sample of arguably type-X freshmen (those who got themselves elected to the seventh Parliament). Table 8 displays various models estimated using all freshmen (columns 1, 3, 5, and 7) as well as type-X freshmen (columns 2, 4, 6 and 8). The estimated coefficients are not larger, but actually smaller in the type-X sample, 
indicating that the results are not likely due to self-selection of type- $\mathrm{X}$ individuals to the seventh Parliament. The exact same analysis is conducted using the seasoned parliamentarian sample. Dropping those seasoned parliamentarians who are not re-elected to the seventh Parliament (using only type-X seasoned parliamentarians) did not change the estimated coefficients.

\section{Summary and Conclusions}

Using data on the members of the European Parliament from 2004 to 2011 we provide estimates of income elasticity of labor supply as well as uncompensated wage elasticity. The compensation structure of the European Parliament and the data compiled by the European Union provide a unique setting for this analysis. This is because for each member of the European Parliament, the labor supply (the number of planetary sessions attended), the daily wage rate (compensation provided for each plenary session attended), and unearned income (fixed salary, which is independent of attendance) are measured with precision. Furthermore, we exploit a major exogenous change in the salary structure that took place in 2009. Prior to July 2009, each member of the European Parliament was paid a salary determined by their home country. As a result, there was considerable variation in salaries, ranging from $€ 10,226$ (Bulgarian members) to $€ 142,146$ (Italian members). Starting with the seventh Parliament in July 2009 the salary of each member of the Parliament is pegged to 38.5 percent of a European Court judge's salary, paid by the EU. Thus, the salary of each member was set to $€ 91,983$ in July 2009, which created an exogenous (and in most cases substantial) increase/decrease in unearned income for the members of the parliament.

We control for personal attributes of the parliamentarians as well as per capita income and the corruption in their home country. We analyze the sample of members who were in the 
European Parliament both before and after the change in the salary structure. We find that an increase in salaries, which represents an increase in unearned income, is statistically significantly related to labor supply with an elasticity of about -0.06 . We also analyze the sample of freshman parliamentarians as well as the sample of seasoned parliamentarians and find similar elasticities in these samples.

Members of the European Parliament also receive per diem compensation for each plenary session they attend. This per diem is above and beyond the compensation for travel expenses related to attending the sessions and therefore it represents the daily wage rate for the parliamentarian. We find that the elasticity of labor supply with respect to this daily wage is about 1.0. We also find that age has a non-linear impact on attendance and that attendance peaks at age 59. The extent of corruption in the home country is negatively related to the number of sessions attended among seasoned parliamentarians (but not among freshmen). For example, a seasoned member of the EU Parliament (one who was has served in the Parliament during a previous term), who represents a country with a moderate level of corruption (e.g. Italy or Romania) attends two fewer plenary sessions (out of an average of 25 sessions) in comparison to a member whose country has a low level of corruption (such as Finland).

The EU Parliamentarians are responsible for passing laws that govern the 27 member countries; they have control over the EU budget, and they supervise the other EU institutions. ${ }^{26}$ Consequently, given the significance of the job, it could be presumed that the attendance records of the parliamentarians would not react to the variation in salaries. The results show that this is not the case and that leisure is a normal good for the members of the European Parliament.

\footnotetext{
${ }^{26}$ For more information about the duties and responsibilities of the EU Parliament see http://europa.eu/about-eu/institutions-bodies/european-parliament/index_en.htm
} 
Furthermore, the estimated elasticity is very similar to those obtained from other settings, such as the inheritance recipients in the U.S. 


\section{Table 1}

European Parliament Plenary Session Dates \& Parliamentarian Salary Sources

\begin{tabular}{lccccc}
\hline Salary Source & Period & Parliament & $\begin{array}{c}\text { Plenary } \\
\text { Sessions }\end{array}$ & Start Date & End Date \\
\hline Home country & 1 & $6^{\text {th }}$ & 23 & July 20,2004 & December 31, 2004 \\
Home country & 2 & $6^{\text {th }}$ & 36 & Jan 1, 2005 & August 31, 2005 \\
Home country & 3 & $6^{\text {th }}$ & 23 & September 1, 2005 & December 31, 2005 \\
Home country & 4 & $6^{\text {th }}$ & 37 & January 1, 2006 & August 31, 2006 \\
Home country & 5 & $6^{\text {th }}$ & 25 & September 1, 2006 & December 31, 2006 \\
Home country & 6 & $6^{\text {th }}$ & 37 & January 1, 2007 & August 31, 2007 \\
Home country & 7 & $6^{\text {th }}$ & 25 & September 1, 2007 & December 31, 2007 \\
Home country & 8 & $6^{\text {th }}$ & 39 & January 1, 2008 & August 31, 2008 \\
Home country & 9 & $6^{\text {th }}$ & 24 & September 1, 2008 & December 31, 2008 \\
Home country & 10 & $6^{\text {th }}$ & 28 & January 1, 2009 & June 13, 2009
\end{tabular}

Election

\begin{tabular}{|c|c|c|c|c|c|}
\hline EU; $€ 91,983$ & 11 & $7^{\text {th }}$ & 23 & July 14, 2009 & December 31, 2009 \\
\hline EU; $€ 93,686$ & 12 & $7^{\text {th }}$ & 35 & January 1, 2010 & August 31, 2010 \\
\hline EU; $€ 93,686$ & 13 & $7^{\text {th }}$ & 24 & September 1, 2010 & December 31, 2010 \\
\hline $\mathrm{EU} ; € 95,483$ & 14 & $7^{\text {th }}$ & 25 & January 1, 2011 & August $31,2011^{*}$ \\
\hline
\end{tabular}


Table 2

Salaries and Distribution of Seats in the European Parliament at the end of the $6^{\text {th }}$ Parliament in June 2009

\begin{tabular}{|c|c|c|c|}
\hline Country & Number of Seats & $\%$ of Seats & $\begin{array}{c}\text { Average } \\
\text { Salary in } \\
\text { Euros }\end{array}$ \\
\hline Austria & 18 & $2.32 \%$ & 110,330 \\
\hline Belgium & 23 & $2.96 \%$ & 72,948 \\
\hline Bulgaria & 18 & $2.32 \%$ & 10,226 \\
\hline Cyprus & 6 & $0.77 \%$ & 44,129 \\
\hline Czech Republic & 24 & $3.09 \%$ & 29,368 \\
\hline Denmark & 14 & $1.80 \%$ & 73,248 \\
\hline Estonia & 6 & $0.77 \%$ & 31,144 \\
\hline Finland & 14 & $1.80 \%$ & 65,779 \\
\hline France & 78 & $10.05 \%$ & 77,838 \\
\hline Germany & 98 & $12.63 \%$ & 85,319 \\
\hline Greece & 24 & $3.09 \%$ & 76,141 \\
\hline Hungary & 24 & $3.09 \%$ & 44,029 \\
\hline Ireland & 12 & $1.55 \%$ & 95,930 \\
\hline Italy & 78 & $10.05 \%$ & 142,146 \\
\hline Latvia & 8 & $1.03 \%$ & 16,276 \\
\hline Lithuania & 13 & $1.68 \%$ & 14,197 \\
\hline Luxembourg & 6 & $0.77 \%$ & 69,613 \\
\hline Malta & 5 & $0.64 \%$ & 16,604 \\
\hline Netherlands & 27 & $3.48 \%$ & 80,474 \\
\hline Poland & 53 & $6.83 \%$ & 29,209 \\
\hline Portugal & 24 & $3.09 \%$ & 50,102 \\
\hline Romania & 33 & $4.25 \%$ & 21,746 \\
\hline Slovakia & 14 & $1.80 \%$ & 15,900 \\
\hline Slovenia & 7 & $0.90 \%$ & 51,815 \\
\hline Spain & 52 & $6.70 \%$ & 41,847 \\
\hline Sweden & 19 & $2.45 \%$ & 65,079 \\
\hline United Kingdom & 78 & $10.05 \%$ & 84,054 \\
\hline
\end{tabular}

Distribution of seats reflects the composition of the European Parliament before the 2009 elections.

Salaries represent average annual salaries paid by home country during the $6^{\text {th }}$ Parliament, between July 2004 and July 2009. 
Table 3A

Summary Statistics

\begin{tabular}{|c|c|c|c|c|}
\hline & $(1)$ & $(2)$ & (3) & $(4)$ \\
\hline Variable & $\begin{array}{l}\text { Whole Sample } \\
\qquad(\mathrm{N}=9,836)\end{array}$ & $\begin{array}{l}\text { Parliamentarians in } \\
\text { the } 6^{\text {th }} \text { Parliament } \& \\
\text { re-elected to the } 7^{\text {th }} \\
(\mathrm{N}=4,775)\end{array}$ & $\begin{array}{c}\text { Freshman } \\
\text { Parliamentarian } \\
\text { sample } \\
(\mathrm{N}=5,533) \\
\end{array}$ & $\begin{array}{c}\text { Seasoned } \\
\text { Parliamentarian } \\
\text { sample } \\
(\mathrm{N}=4,303) \\
\end{array}$ \\
\hline \multirow[t]{2}{*}{ Attendance } & 25.221 & 25.389 & 25.152 & 25.309 \\
\hline & $(6.274)$ & $(6.150)$ & $(6.418)$ & $(6.085)$ \\
\hline \multirow[t]{2}{*}{ Salary $(1,000 €)$} & 76.679 & 75.982 & 68.590 & 87.079 \\
\hline & $(30.355)$ & $(28.190)$ & $(34.458)$ & (19.682) \\
\hline \multirow[t]{2}{*}{ Per diem pay } & 284.967 & 284.968 & 284.459 & 285.620 \\
\hline & $(12.860)$ & $(12.919)$ & $(12.596)$ & $(13.165)$ \\
\hline \multirow[t]{2}{*}{ Real salary } & 71.927 & 71.228 & 64.386 & 81.624 \\
\hline & $(28.300)$ & $(26.106)$ & $(32.106)$ & $(18.392)$ \\
\hline \multirow[t]{2}{*}{ Real per diem pay } & 268.113 & 268.004 & 268.293 & 267.880 \\
\hline & $(8.518)$ & $(8.471)$ & $(8.710)$ & $(8.259)$ \\
\hline \multirow[t]{2}{*}{ Tenure in $6^{\text {th }}$ or $7^{\text {th }}$ parliament } & 5.801 & 7.259 & 4.466 & 7.518 \\
\hline & $(3.707)$ & $(3.993)$ & $(2.793)$ & $(4.019)$ \\
\hline \multirow[t]{2}{*}{ Political group attendance $(\%)$} & 87.619 & 87.764 & 87.413 & 87.883 \\
\hline & $(2.778)$ & $(2.680)$ & $(2.820)$ & $(2.700)$ \\
\hline \multirow[t]{2}{*}{ Age } & 53.311 & 52.871 & 51.277 & 55.927 \\
\hline & $(10.137)$ & $(9.569)$ & $(10.612)$ & $(8.828)$ \\
\hline \multirow[t]{2}{*}{ Female } & 0.314 & 0.324 & 0.311 & 0.318 \\
\hline & $(0.464)$ & $(0.468)$ & $(0.463)$ & $(0.466)$ \\
\hline \multirow[t]{2}{*}{ PhD-MD } & 0.244 & 0.256 & 0.269 & 0.213 \\
\hline & $(0.430)$ & $(0.436)$ & $(0.443)$ & $(0.410)$ \\
\hline \multirow[t]{2}{*}{ Corruption } & 20.083 & 18.498 & 23.497 & 15.692 \\
\hline & $(12.270)$ & (11.776) & (12.790) & $(9.976)$ \\
\hline \multirow[t]{2}{*}{ Per capita GDP } & 27.148 & 27.797 & 24.835 & 30.122 \\
\hline & $(8.126)$ & $(8.104)$ & (7.908) & $(7.403)$ \\
\hline \multirow[t]{2}{*}{ Member in $1^{\text {st }}$ Parliament } & 0.011 & 0.006 & & 0.026 \\
\hline & $(0.106)$ & $(0.076)$ & & $(0.159)$ \\
\hline \multirow[t]{2}{*}{ Member in $2^{\text {nd }}$ Parliament } & 0.031 & 0.023 & & 0.071 \\
\hline & $(0.173)$ & $(0.151)$ & & $(0.256)$ \\
\hline \multirow[t]{2}{*}{ Member in $3^{\text {rd }}$ Parliament } & 0.063 & 0.072 & & 0.145 \\
\hline & $(0.244)$ & $(0.259)$ & & $(0.352)$ \\
\hline \multirow[t]{2}{*}{ Member in $4^{\text {th }}$ Parliament } & 0.165 & 0.182 & & 0.378 \\
\hline & $(0.371)$ & $(0.386)$ & & $(0.485)$ \\
\hline \multirow[t]{2}{*}{ Member in $5^{\text {th }}$ Parliament } & 0.334 & 0.384 & & 0.764 \\
\hline & $(0.472)$ & $(0.486)$ & & $(0.425)$ \\
\hline \multirow[t]{2}{*}{ Member in $6^{\text {th }}$ Parliament } & 0.852 & 1.000 & 0.746 & 0.988 \\
\hline & $(0.356)$ & $(0.000)$ & $(0.436)$ & $(0.110)$ \\
\hline
\end{tabular}


Table 3A (concluded)

\begin{tabular}{lcccc}
\hline & $(1)$ & $(2)$ & $(3)$ & $(4)$ \\
\hline Variable & $\begin{array}{c}\text { Whole Sample } \\
(\mathrm{N}=9,836)\end{array}$ & $\begin{array}{c}\text { Re-elected to } 7^{\text {th }} \\
\text { Parliament } \\
(\mathrm{N}=4,775)\end{array}$ & $\begin{array}{c}\text { Rookie MEPs } \\
(\mathrm{N}=5,533)\end{array}$ & $\begin{array}{c}\text { Seasoned MEPs } \\
(\mathrm{N}=4,303)\end{array}$ \\
\hline Member in 7 $7^{\text {th }}$ Parliament & 0.634 & 1.000 & 0.616 & 0.657 \\
& $(0.482)$ & $(0.000)$ & $(0.487)$ & $(0.475)$ \\
\hline
\end{tabular}

The unit of observation is parliamentarian-plenary session (There are 14 plenary sessions during the sixth and the seventh Parliaments; see Table 1) 
Table 3B

Individual Descriptive Statistics

\begin{tabular}{lccccc}
\hline Variable & $\mathrm{N}$ & Mean & Std. Dev & Min & Max \\
\hline Female & 1,151 & 0.321 & 0.467 & 0 & 1 \\
PhD-MD & 1,151 & 0.222 & 0.416 & 0 & 1 \\
Age & 1,151 & 50.381 & 10.323 & 24 & 81 \\
Member in ${ }^{\text {st }}$ Parliament & 1,151 & 0.010 & 0.097 & 0 & 1 \\
Member in $2^{\text {nd }}$ Parliament & 1,151 & 0.025 & 0.157 & 0 & 1 \\
Member in $3^{\text {rd }}$ Parliament & 1,151 & 0.047 & 0.212 & 0 & 1 \\
Member in 4 $4^{\text {th }}$ Parliament & 1,151 & 0.124 & 0.330 & 0 & 1 \\
Member in $5^{\text {th }}$ Parliament & 1,151 & 0.252 & 0.434 & 0 & 1 \\
Member in $6^{\text {th }}$ Parliament & 1,151 & 0.675 & 0.469 & 0 & 1 \\
Member in $7^{\text {th }}$ Parliament & 1,151 & 0.639 & 0.481 & 0 & 1 \\
Corruption & 1,151 & 21.428 & 13.139 & 1 & 48 \\
Per Capita GDP $(1,000 \$)$ & 1,151 & 26.167 & 8.230 & 10.74826 & 68.85345 \\
\hline
\end{tabular}

There are 1,115 unique parliamentarians who served in the sixth and the seventh parliaments between 2004 and 2011. The summary statistics in the table pertain to the first time the parliamentarian is observed during this time period. This date is either July 2004 (for those who are elected to the sixth parliament), July 2009 (for those who were elected to the seventh Parliament and who were not in the sixth Parliament), or 2007 for the members from Romania and Bulgaria as these countries became members of the EU in 2007.

Corruption is the percentile ranking of the home country in the world corruption distribution. 
Table 4

The Impact of Salary on Attendance to the Plenary Sessions

\begin{tabular}{|c|c|c|c|c|}
\hline & \multicolumn{2}{|c|}{ Whole Sample } & \multicolumn{2}{|c|}{$\begin{array}{l}\text { Re-elected for the } 7^{\text {th }} \\
\text { Parliamentary Term }\end{array}$} \\
\hline & $(1)$ & $(2)$ & $(3)$ & $(4)$ \\
\hline \multirow[t]{2}{*}{ Real Salary (1,000 Euros) } & $-0.013 * * *$ & $-0.026 * * *$ & $-0.014 * * *$ & $-0.020 * * *$ \\
\hline & $(0.004)$ & $(0.004)$ & $(0.004)$ & $(0.006)$ \\
\hline \multirow[t]{2}{*}{ Tenure in $6^{\text {th }}$ or $7^{\text {th }}$ parliament } & 0.918 & 0.004 & 1.763 & 0.011 \\
\hline & $(0.840)$ & $(0.049)$ & $(1.448)$ & $(0.063)$ \\
\hline \multirow[t]{2}{*}{ Real per diem pay } & $0.094 * * *$ & $0.094 * * *$ & $0.084 * * *$ & $0.093 * *$ \\
\hline & $(0.013)$ & $(0.029)$ & $(0.018)$ & $(0.038)$ \\
\hline \multirow[t]{2}{*}{ Political group attendance (\%) } & 0.032 & $0.095 * *$ & $0.087 * *$ & $0.199 * * *$ \\
\hline & $(0.028)$ & $(0.042)$ & $(0.036)$ & $(0.062)$ \\
\hline \multirow[t]{2}{*}{ Per capita GDP } & 0.068 & -0.007 & $0.116^{*}$ & -0.010 \\
\hline & $(0.049)$ & $(0.017)$ & $(0.060)$ & $(0.026)$ \\
\hline \multirow[t]{2}{*}{ Corruption } & -0.007 & $-0.017 *$ & -0.002 & $-0.034 * *$ \\
\hline & $(0.014)$ & $(0.010)$ & $(0.017)$ & $(0.017)$ \\
\hline \multirow[t]{2}{*}{ Age } & & $0.236 * * *$ & & $0.298 * * *$ \\
\hline & & $(0.067)$ & & $(0.099)$ \\
\hline \multirow[t]{2}{*}{$\mathrm{Age}^{2}$} & & $-0.002 * * *$ & & $-0.003 * * *$ \\
\hline & & $(0.001)$ & & $(0.001)$ \\
\hline \multirow[t]{2}{*}{ Female } & & 0.004 & & -0.158 \\
\hline & & $(0.170)$ & & $(0.232)$ \\
\hline \multirow[t]{2}{*}{ PhD-MD } & & 0.015 & & -0.128 \\
\hline & & $(0.211)$ & & $(0.280)$ \\
\hline $\mathrm{N}$ & 9,836 & 9,836 & 4,775 & 4,775 \\
\hline \multirow{2}{*}{$\begin{array}{l}\text { Individual fixed effects } \\
\text { Indicators for previous } \\
\text { parliamentary memberships }\end{array}$} & Yes & No & Yes & No \\
\hline & No & Yes & No & Yes \\
\hline
\end{tabular}

Notes: Dependent variable is the number of plenary sessions a parliamentarian attended in a period. The first two columns employ the whole sample, and the last two columns employ the parliamentarians who served in both the $6^{\text {th }}$ and the $7^{\text {th }}$ Parliaments. Odd-numbered columns report the results from regressions that include individual fixed effects and even-numbered column report the results of the models that include individual characteristics. All regressions include indicators for periods and an overall time trend. Clustered standard errors are reported in parentheses. ${ }^{*}, * *$, and $* * *$ indicate significance at $10 \%, 5 \%$ and $1 \%$, respectively. 
Table 5

The Impact of Salary on Attendance to the Plenary Sessions

Freshman and Seasoned Parliamentarians

\begin{tabular}{lccc}
\hline & Freshmen & \multicolumn{2}{c}{ Seasoned Members } \\
\hline Real Salary (1,000 Euros) & $(1)$ & $(2)$ & $(3)$ \\
Tenure in $6^{\text {th }}$ or $7^{\text {th }}$ parliament & $-0.030^{* * *}$ & $-0.027^{* * *}$ & -0.012 \\
& $(0.005)$ & $(0.007)$ & $(0.007)$ \\
Real per diem pay & 0.038 & $0.912^{* *}$ & $-0.116^{* *}$ \\
& $(0.064)$ & $(0.462)$ & $(0.055)$ \\
Political group attendance (\%) & $0.113^{* * *}$ & $0.134^{* * *}$ & $0.157^{* * *}$ \\
& $(0.016)$ & $(0.016)$ & $(0.034)$ \\
Per capita GDP & 0.072 & 0.059 & $0.116^{*}$ \\
& $(0.049)$ & $(0.039)$ & $(0.060)$ \\
Corruption & 0.013 & 0.093 & -0.023 \\
& $(0.020)$ & $(0.068)$ & $(0.026)$ \\
Age & -0.002 & -0.030 & $-0.057^{* * *}$ \\
& $(0.011)$ & $(0.027)$ & $(0.016)$ \\
Age & & & $0.298^{* * *}$ \\
& $0.211^{* *}$ & & $(0.111)$ \\
Female & $(0.082)$ & & $-0.003^{* *}$ \\
PhD-MD & $-0.002^{* *}$ & & $(0.001)$ \\
& $(0.001)$ & & -0.163 \\
N & 0.144 & & $(0.249)$ \\
parliamentary membership & $(0.218)$ & & 0.057 \\
\hline
\end{tabular}

The dependent variable is the number of plenary sessions attended in a period. The first column employs the sample of freshman parliamentarians (who are elected to the parliament for first time), and the last two columns employ the sample of seasoned parliamentarians (who had been elected to the parliament at least once before All regressions include indicators for periods and an overall time trend. Clustered standard errors are reported in parentheses. *, **, and $* * *$ indicate significance at $10 \%, 5 \%$ and $1 \%$, respectively. 


\section{Table 6}

The Impact of Salary on Average Attendance to the Plenary Sessions by Parliament

\begin{tabular}{lcccc}
\hline & $\begin{array}{c}\text { Re-elected to the } 7^{\text {th }} \\
\text { Parliamentary }\end{array}$ & $\begin{array}{c}\text { Freshman } \\
\text { Members }\end{array}$ & $\begin{array}{c}\text { Seasoned } \\
\text { Members }\end{array}$ & $\begin{array}{c}\text { Country } \\
\text { Level }\end{array}$ \\
\hline & First Differences & OLS & OLS & FE \\
\hline Real Salary (1,000 Euros) & $(1)$ & $(2)$ & $(3)$ & $(4)$ \\
\hline & $-0.019^{* * *}$ & $-0.029^{* * *}$ & $-0.013^{*}$ & $-0.022^{* *}$ \\
Tenure in $6^{\text {th }}$ or $7^{\text {th }}$ parliament & $(0.005)$ & $(0.005)$ & $(0.007)$ & $(0.009)$ \\
& 0.860 & 0.465 & $-0.111^{*}$ & 1.610 \\
Real per diem pay & $(0.734)$ & $(0.619)$ & $(0.057)$ & $(1.060)$ \\
& $-0.452^{* *}$ & 0.044 & -0.040 & -0.045 \\
Political group attendance (\%) & $(0.229)$ & $(0.169)$ & $(0.068)$ & $(0.061)$ \\
& 0.086 & $0.122^{* *}$ & $0.168^{* *}$ & 0.324 \\
Per capita GDP & $(0.058)$ & $(0.057)$ & $(0.067)$ & $(0.198)$ \\
& $0.210^{* * *}$ & 0.003 & -0.027 & $-0.200^{*}$ \\
Corruption & $(0.075)$ & $(0.020)$ & $(0.024)$ & $(0.117)$ \\
& 0.019 & -0.013 & $-0.048^{* * *}$ & -0.076 \\
Age & $(0.026)$ & $(0.010)$ & $(0.015)$ & $(0.046)$ \\
& & $0.198^{* * *}$ & $0.347^{* * *}$ & $1.005^{* * *}$ \\
Age & & $(0.071)$ & $(0.109)$ & $(0.355)$ \\
& & $-0.002^{* * *}$ & $-0.003^{* * *}$ & $-0.009^{* *}$ \\
Female & & $(0.001)$ & $(0.001)$ & $(0.004)$ \\
& & 0.198 & -0.178 & -1.005 \\
PhD-MD & & $(0.194)$ & $(0.228)$ & $(1.244)$ \\
& & 0.010 & -0.060 & $3.460^{*}$ \\
$\mathrm{~N}$ & & $(0.246)$ & $(0.264)$ & $(1.931)$ \\
\hline
\end{tabular}

The dependent variable in the first three columns is the average number of plenary sessions a parliamentarian attended in a parliamentary term. The dependent variable in the fourth column is the average number of plenary sessions parliamentarians from a country attended in a parliamentary term. First regression is estimated with OLS on the first differences of the variables. Only those who were re-elected for the $7^{\text {th }}$ parliamentary term are included in the first column. The samples in the second and third columns employ freshman and seasoned parliamentarians, respectively. Regressions include full set of control variables. All regressions except the first include an indicator for the seventh parliamentary term. Fourth column includes country fixed effects. Clustered standard errors are reported in parentheses. ${ }^{*}, * *$, and $* * *$ indicate significance at $10 \%, 5 \%$ and $1 \%$, respectively. 


\section{Table 7}

The Impact of Salary on Attendance to the Plenary Sessions Freshman and Seasoned Parliamentarians (Using the first 4 plenary sessions in the $6^{\text {th }}$ and $7^{\text {th }}$ Parliaments)

\begin{tabular}{lccc}
\hline & Freshmen & \multicolumn{2}{c}{ Seasoned Members } \\
\hline Real Salary (1,000 Euros) & $(1)$ & $(2)$ & $(3)$ \\
& $-0.031^{* * *}$ & $-0.033^{* * *}$ & $-0.015^{*}$ \\
Tenure in 6 ${ }^{\text {th }}$ or $7^{\text {th }}$ parliament & $(0.006)$ & $(0.007)$ & $(0.008)$ \\
& $-0.466^{*}$ & 0.480 & $-0.096^{*}$ \\
Real per diem pay & $(0.248)$ & $(0.529)$ & $(0.057)$ \\
& $0.175^{* * *}$ & $1.695^{* * *}$ & $0.143^{* * *}$ \\
Political group attendance (\%) & $(0.037)$ & $(0.040)$ & $(0.035)$ \\
& $0.101^{* *}$ & $0.110^{* *}$ & $0.172^{* * *}$ \\
Per capita GDP & $(0.050)$ & $(0.051)$ & $(0.057)$ \\
& 0.010 & $0.137^{*}$ & -0.028 \\
Corruption & $(0.020)$ & $(0.081)$ & $(0.024)$ \\
& 0.000 & -0.014 & $-0.047^{* * *}$ \\
Age & $(0.010)$ & $(0.027)$ & $(0.015)$ \\
& 0.121 & & $0.325^{* * *}$ \\
Age & $(0.076)$ & & $(0.109)$ \\
& -0.001 & & $-0.003^{* * *}$ \\
Female & $(0.001)$ & & $(0.001)$ \\
PhD-MD & 0.160 & & -0.195 \\
& $(0.201)$ & & $(0.220)$ \\
N & -0.003 & & -0.061 \\
Individual fixed effects & $(0.255)$ & & $(0.266)$ \\
\hline
\end{tabular}

The dependent variable is the number of plenary sessions attended in a period. All regression employ 8 plenary sessions (The 4 plenary sessions that took place between 2009 and 2011 in the seventh Parliament and the first 4 plenary sessions of the sixth parliament). The first column employs the sample of freshman parliamentarians (who are elected to the parliament for first time), and the last two columns employ the sample of seasoned parliamentarians (who had been elected to the parliament at least once before All regressions include indicators for periods and an overall time trend. Clustered standard errors are reported in parentheses. *, ${ }^{* *}$, and $* * *$ indicate significance at $10 \%, 5 \%$ and $1 \%$, respectively. 
Table 8

Responsiveness of Freshmen Parliamentarians

\begin{tabular}{|c|c|c|c|c|c|c|c|c|}
\hline & \multicolumn{4}{|c|}{$\begin{array}{l}\text { Dependent variable: } \\
\text { Days Attended in Each Period }\end{array}$} & \multicolumn{4}{|c|}{$\begin{array}{l}\text { Dependent variable: } \\
\text { Average Attendance in } 6^{\text {th }} \text { or } 7^{\text {th }} \text { Terms }\end{array}$} \\
\hline & \multicolumn{2}{|c|}{ All Periods } & \multicolumn{2}{|c|}{$\begin{array}{c}\text { First Four Periods of each } \\
\text { Parliament }\end{array}$} & \multicolumn{2}{|c|}{ All Periods } & \multicolumn{2}{|c|}{$\begin{array}{c}\text { First Four Periods of each } \\
\text { Parliament } \\
\end{array}$} \\
\hline & $\begin{array}{c}\text { All } \\
\text { Freshmen }\end{array}$ & $\begin{array}{c}\text { Type-X } \\
\text { Freshmen }\end{array}$ & $\begin{array}{c}\text { All } \\
\text { Freshmen } \\
\end{array}$ & $\begin{array}{c}\text { Type-X } \\
\text { Freshmen }\end{array}$ & $\begin{array}{c}\text { All } \\
\text { Freshmen }\end{array}$ & $\begin{array}{c}\text { Type-X } \\
\text { Freshmen }\end{array}$ & $\begin{array}{c}\text { All } \\
\text { Freshmen }\end{array}$ & $\begin{array}{c}\text { Type-X } \\
\text { Freshmen }\end{array}$ \\
\hline & $(1)$ & $(2)$ & (3) & (4) & $(5)$ & $(6)$ & $(7)$ & $(8)$ \\
\hline Real Salary (1,000 Euros) & $\begin{array}{c}-0.030 * * * \\
(0.005)\end{array}$ & $\begin{array}{c}-0.024 * * * \\
(0.008)\end{array}$ & $\begin{array}{c}-0.031 * * * \\
(0.006)\end{array}$ & $\begin{array}{c}-0.024 * * \\
(0.010)\end{array}$ & $\begin{array}{c}-0.029 * * * \\
(0.005)\end{array}$ & $\begin{array}{c}-0.028 * * * \\
(0.007)\end{array}$ & $\begin{array}{c}-0.029 * * * \\
(0.006)\end{array}$ & $\begin{array}{c}-0.020 * * \\
(0.009)\end{array}$ \\
\hline Tenure in $6^{\text {th }}$ or $7^{\text {th }}$ parliament & $\begin{array}{c}0.038 \\
(0.064)\end{array}$ & $\begin{array}{l}0.191 * * \\
(0.096)\end{array}$ & $\begin{array}{l}-0.466^{*} \\
(0.248)\end{array}$ & $\begin{array}{l}-0.128 \\
(0.264)\end{array}$ & $\begin{array}{c}0.465 \\
(0.619)\end{array}$ & $\begin{array}{c}1.492 * \\
(0.866)\end{array}$ & $\begin{array}{c}4.533 * * * \\
(1.129)\end{array}$ & $\begin{array}{c}3.801 * * * \\
(1.177)\end{array}$ \\
\hline Real per diem pay & $\begin{array}{c}0.113 * * * \\
(0.016)\end{array}$ & $\begin{array}{c}0.091 * * * \\
(0.021)\end{array}$ & $\begin{array}{c}0.175 * * * \\
(0.037)\end{array}$ & $\begin{array}{c}0.131 * * * \\
(0.043)\end{array}$ & $\begin{array}{c}0.044 \\
(0.169)\end{array}$ & $\begin{array}{c}0.277 \\
(0.256)\end{array}$ & $\begin{array}{c}2.461 * * * \\
(0.388)\end{array}$ & $\begin{array}{c}1.988 * * * \\
(0.456)\end{array}$ \\
\hline Political group attendance $(\%)$ & $\begin{array}{c}0.072 \\
(0.049)\end{array}$ & $\begin{array}{c}0.169 * * * \\
(0.054)\end{array}$ & $\begin{array}{c}0.101 * * \\
(0.050)\end{array}$ & $\begin{array}{c}0.224 * * * \\
(0.059)\end{array}$ & $\begin{array}{c}0.122 * * \\
(0.057)\end{array}$ & $\begin{array}{c}0.192 * * * \\
(0.064)\end{array}$ & $\begin{array}{l}0.114^{*} \\
(0.059)\end{array}$ & $\begin{array}{c}0.146 * * \\
(0.065)\end{array}$ \\
\hline Per capita GDP & $\begin{array}{c}0.013 \\
(0.020)\end{array}$ & $\begin{array}{l}-0.015 \\
(0.022)\end{array}$ & $\begin{array}{c}0.010 \\
(0.020)\end{array}$ & $\begin{array}{l}-0.011 \\
(0.023)\end{array}$ & $\begin{array}{c}0.003 \\
(0.020)\end{array}$ & $\begin{array}{l}-0.013 \\
(0.022)\end{array}$ & $\begin{array}{c}0.000 \\
(0.021)\end{array}$ & $\begin{array}{l}-0.012 \\
(0.023)\end{array}$ \\
\hline Corruption & $\begin{array}{l}-0.002 \\
(0.011)\end{array}$ & $\begin{array}{c}-0.035 * * * \\
(0.012)\end{array}$ & $\begin{array}{c}0.000 \\
(0.010)\end{array}$ & $\begin{array}{l}-0.021 \\
(0.013)\end{array}$ & $\begin{array}{l}-0.013 \\
(0.010)\end{array}$ & $\begin{array}{c}-0.033 * * * \\
(0.011)\end{array}$ & $\begin{array}{l}-0.000 \\
(0.010)\end{array}$ & $\begin{array}{c}-0.024 * * \\
(0.011)\end{array}$ \\
\hline Age & $\begin{array}{c}0.211 * * \\
(0.082)\end{array}$ & $\begin{array}{c}0.121 \\
(0.092)\end{array}$ & $\begin{array}{c}0.121 \\
(0.076)\end{array}$ & $\begin{array}{c}0.047 \\
(0.089)\end{array}$ & $\begin{array}{c}0.198 * * * \\
(0.071)\end{array}$ & $\begin{array}{c}0.106 \\
(0.084)\end{array}$ & $\begin{array}{l}0.140 * \\
(0.079)\end{array}$ & $\begin{array}{c}0.079 \\
(0.085)\end{array}$ \\
\hline $\operatorname{Age}^{2}$ & $\begin{array}{c}-0.002 * * \\
(0.001)\end{array}$ & $\begin{array}{l}-0.001 \\
(0.001)\end{array}$ & $\begin{array}{l}-0.001 \\
(0.001)\end{array}$ & $\begin{array}{l}-0.000 \\
(0.001)\end{array}$ & $\begin{array}{c}-0.002 * * * \\
(0.001)\end{array}$ & $\begin{array}{l}-0.001 \\
(0.001)\end{array}$ & $\begin{array}{l}-0.001 * \\
(0.001)\end{array}$ & $\begin{array}{l}-0.001 \\
(0.001)\end{array}$ \\
\hline Female & $\begin{array}{c}0.144 \\
(0.218)\end{array}$ & $\begin{array}{c}0.117 \\
(0.224)\end{array}$ & $\begin{array}{c}0.160 \\
(0.201)\end{array}$ & $\begin{array}{c}0.069 \\
(0.212)\end{array}$ & $\begin{array}{c}0.198 \\
(0.194)\end{array}$ & $\begin{array}{c}0.142 \\
(0.199)\end{array}$ & $\begin{array}{c}0.204 \\
(0.204)\end{array}$ & $\begin{array}{c}0.093 \\
(0.203)\end{array}$ \\
\hline PhD-MD & $\begin{array}{l}-0.029 \\
(0.267)\end{array}$ & $\begin{array}{c}0.018 \\
(0.289)\end{array}$ & $\begin{array}{c}-0.003 \\
(0.255)\end{array}$ & $\begin{array}{c}-0.246 \\
(0.282)\end{array}$ & $\begin{array}{c}0.010 \\
(0.246)\end{array}$ & $\begin{array}{l}-0.015 \\
(0.271)\end{array}$ & $\begin{array}{l}-0.012 \\
(0.260)\end{array}$ & $\begin{array}{c}0.096 \\
(0.279)\end{array}$ \\
\hline $\mathrm{N}$ & 5,533 & 3,406 & 2,852 & 1,832 & 850 & 585 & 734 & 545 \\
\hline
\end{tabular}

The dependent variable in the first four columns is the number of plenary sessions a parliamentarian attended in a period. The dependent variable in the last four columns is the average number of plenary sessions a parliamentarian attended in a parliamentary term. All regressions employ OLS on the sample indicated at the top of the column. Type-X freshmen constitute a subset of All Freshmen. They are those who are either: 1) Newly elected to the $7^{\text {th }}$ Parliament 2) Are freshmen in the $6^{\text {th }}$ Parliament and will be re-elected to the $7^{\text {th }}$ Parliament. Standard errors clustered at the individual level are reported in the parentheses. *,**, and *** indicate significance at $10 \%, 5 \%$ and $1 \%$, respectively. 
Figure 1

Salaries of the Members of the European Parliament by Country of Representation

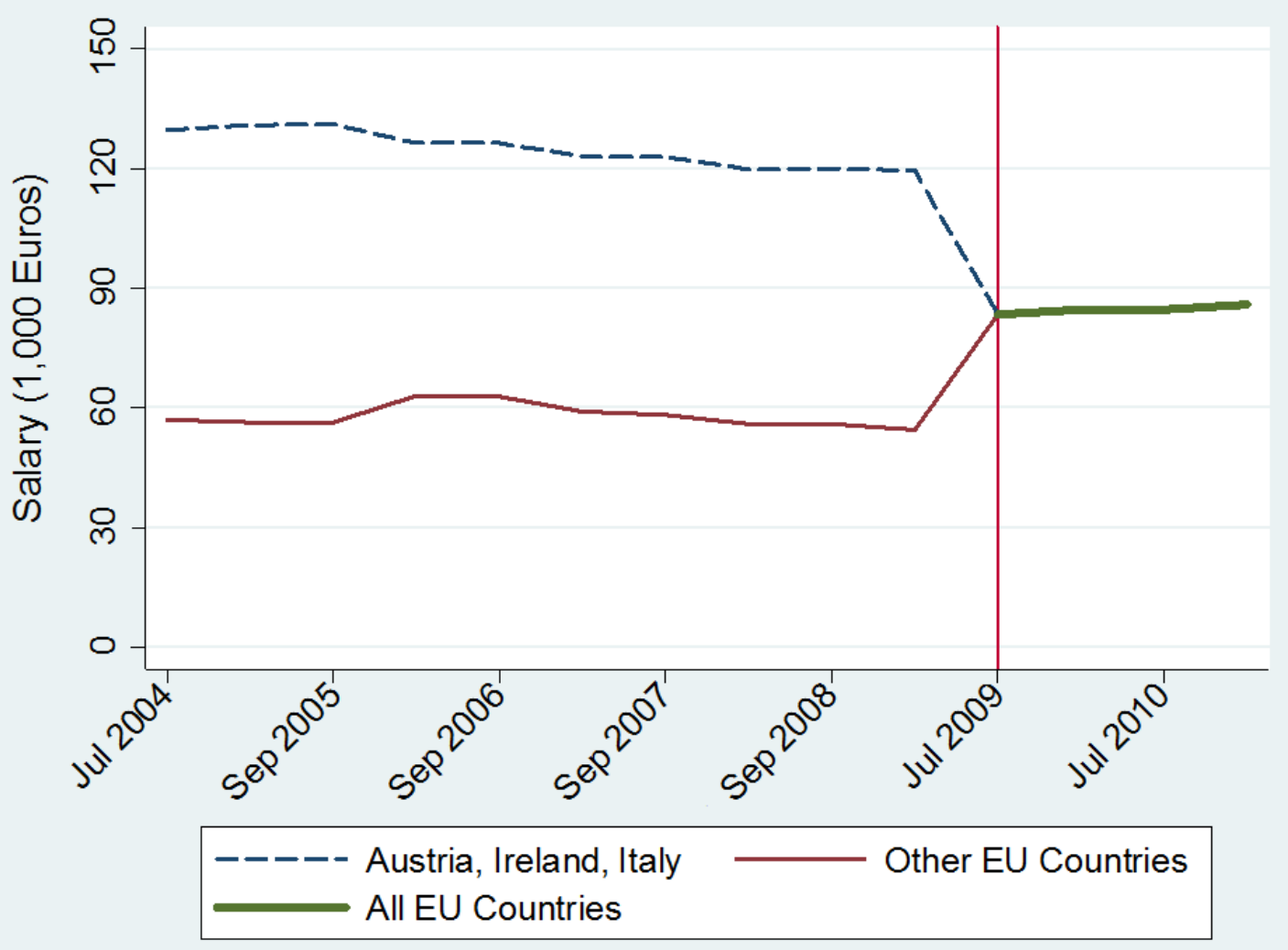


Figure 2

Difference in Salary and Attendance between the Austrian, Irish and Italian Members, and Other Members

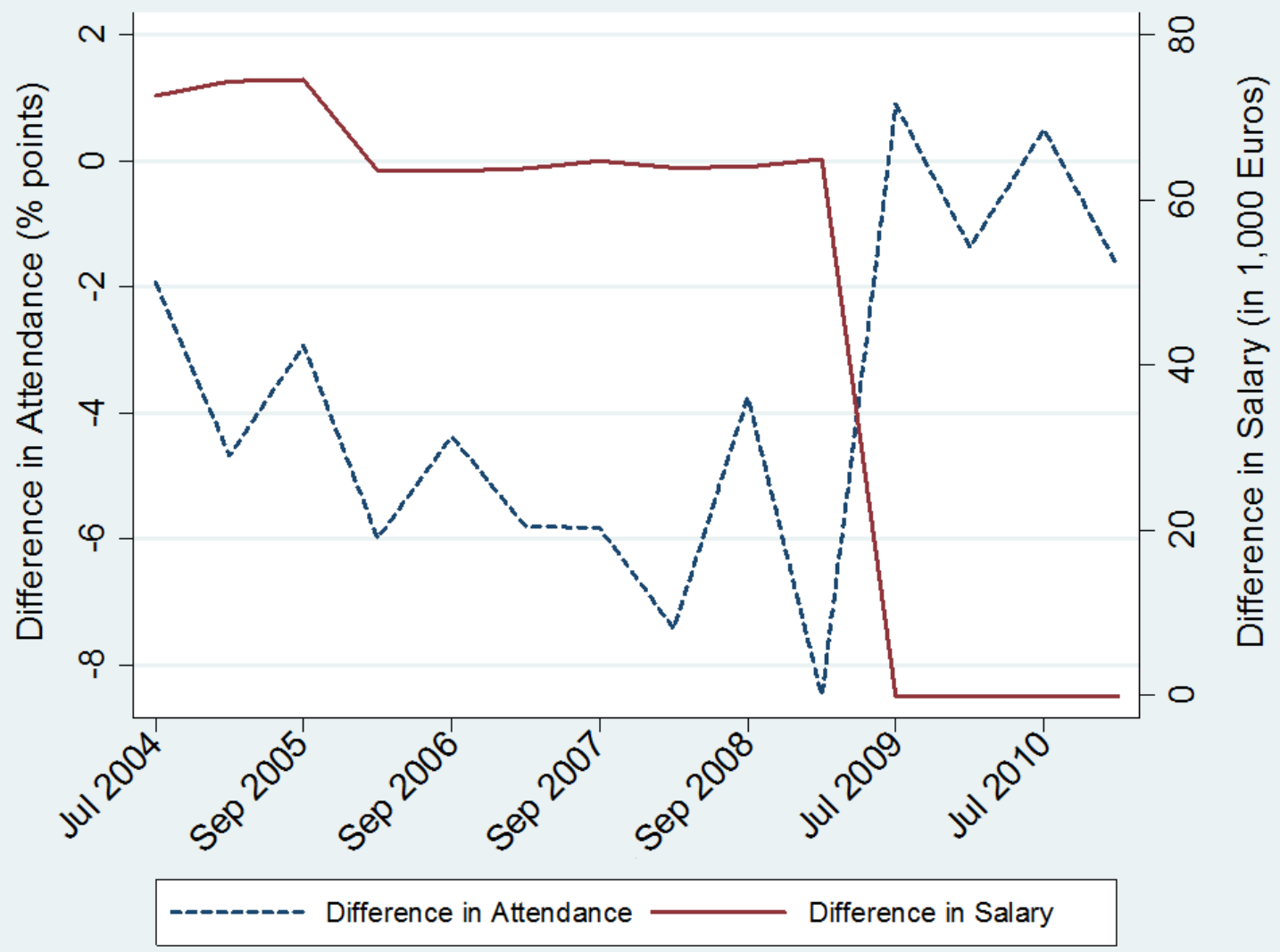

Notes: The dashed line represents the difference in the attendance rates between the members from High-Salary countries and Low-Salary countries. The solid line displays the difference in salaries between the members from High-Salary countries and Low-Salary countries. 
Figure 3

Re-election Rate and Change in Salary by Country

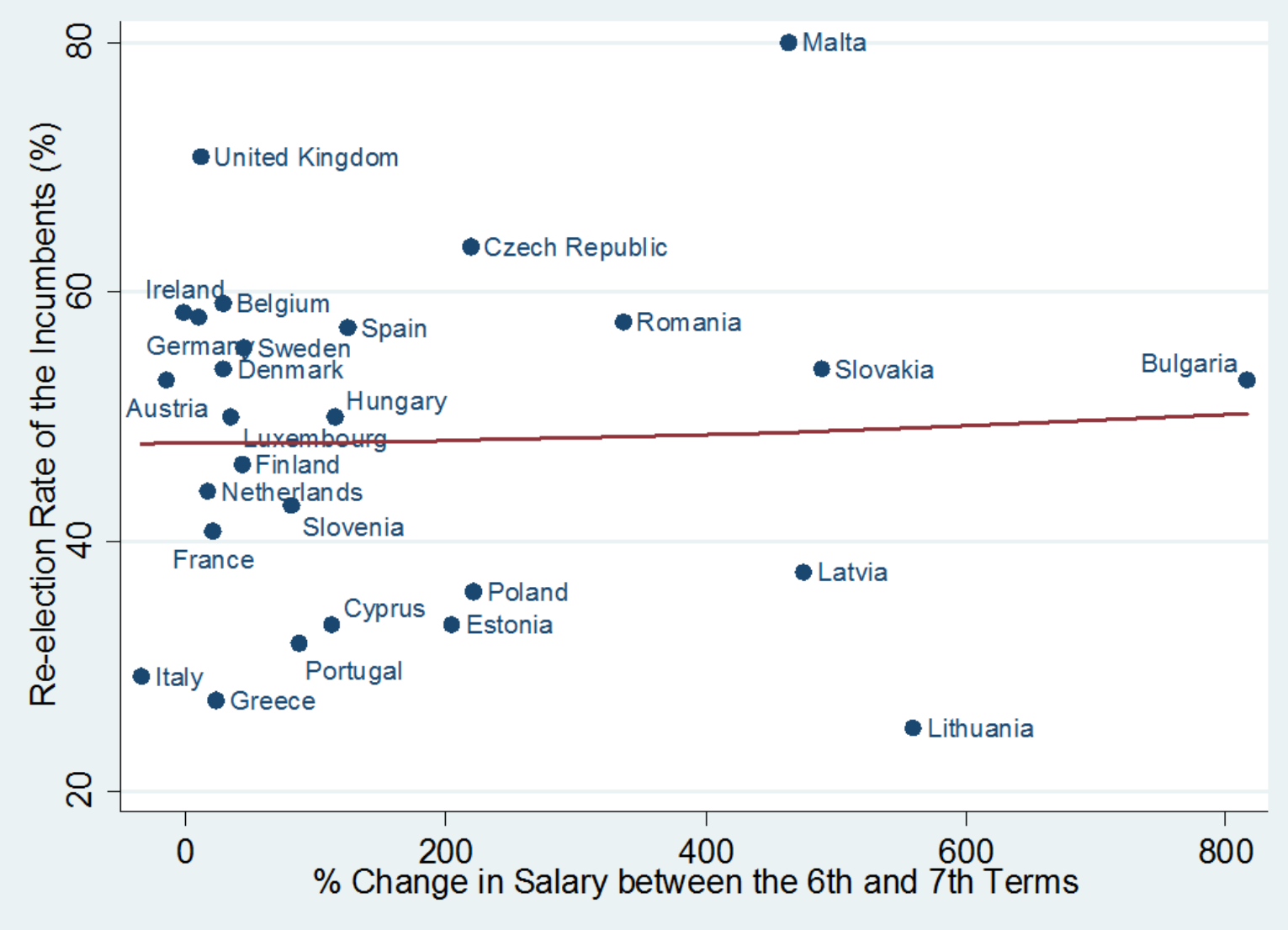


Figure 4

Re-election rates to the $6^{\text {th }}$ and the $7^{\text {th }}$ Terms of the European Parliament by Country

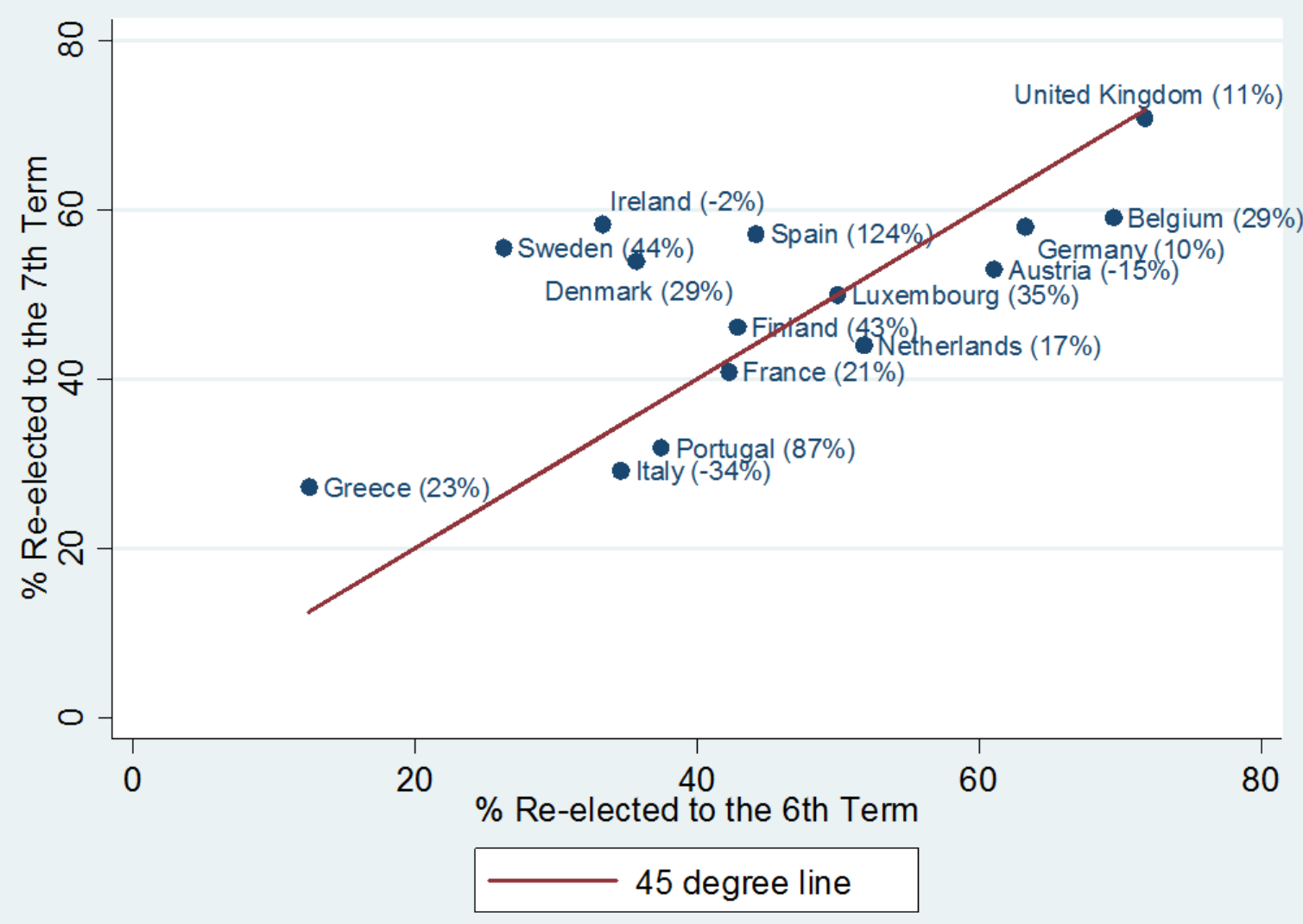




\section{References}

Alesina, Alberto, Edward Glaeser, and Bruce Sacerdote, 2005, "Work and Leisure in the United States and Europe: Why So Different?" NBER Macroeconomics Annual, 20, pp. 1-64.

Arellano, Manuel and Costas Meghir, 1992, "Female Labour Supply and On-the-Job Search: an Empirical Model Estimated Using Complementary Data Sets,” Review of Economic $\underline{\text { Studies, }}$ 59, pp.537-559.

Arrufat, J. L., and A. Zabalza, 1986, "Female Labor Supply with Taxation, Random Preferences, and Optimization Errors," Econometrica, 54 (1), pp. 47-63.

Blomquist, N.S. and U. Hansson-Brusewitz, 1990, "The Effect of Taxes on Male and Female Labor Supply in Sweden," Journal of Human Resources, 25(3), pp. 317-357.

Blundell, Richard, and Thomas MaCurdy, "Labor Supply: a Review of AlternativeApproaches," Handbook of Labor Economics, Orley C. Ashenfelter and David Card (Eds.) Vol. 3A, (Amsterdam and NY: North-Holland, 1999), pp. 1559-1695.

Colombino, Ugo, and Daniela Del Boca, 1990, "The Effect of Taxes on Labor Supply in Italy," Journal of Human Resources, 25(3), pp. 390-414.

Dickinson, David L., 1999, “An Experimental Examination of Labor Supply and Work Intensities," Journal of Labor Economics, 17 (4), pp, 638-670.

Fisman, Raymond, and Edward Miguel, 2007,"Corruption, Norms, and legal Enforcement: Evidence from Diplomatic Tickets,” Journal of Political Economy, 115(6), pp. 1020-48.

Hix, Simon, Abdul Noury and Gerard Roland, 2006, "Dimensions of Politics in the European Parliament", American Journal of Political Science, 50(2) pp. 494-511.

Holtz-Eakin, Douglas, David Joulfaian, and Harvey S. Rosen, 1993, “The Carnegie Conjecture: Some Empirical Evidence," Quarterly Journal of Economics, 108 (2), pp. 413-435. 
Imbens, Guido W., Donald B. Rubin, and Bruce I. Sacerdote, 2001, "Estimating the Effect of Unearned Income on Labor Earnings, Savings, and Consumption: Evidence from a Survey of Lottery Players,” American Economic Review, 91 (4), pp. 778-794.

Joulfaian, David, and Mark O. Wilhelm, 1994, "Inheritance and Labor Supply," Journal of Human Resources, 29(4), pp. 1205-1234.

Mocan, Naci, "Corruption, Corruption Perception, and Economic Growth," Economic Performance in the Middle East and North Africa: Institutions, Corruption and Reform, S. Sayan (ed.), (London: Routledge, 2009).

Mocan, Naci , 2008, "What Determines Corruption? International Evidence from Micro Data," Economic Inquiry, Vol. 46 (4), pp. 493-510.

Pencavel, John, "Labor Supply of Men: a Survey," Handbook of Labor Economics, Orley C. Ashenfelter and Richard Layard (Eds.), Vol. 1, (Amsterdam and NY: North-Holland, 1986), pp. 3-102.

Van Soest, Arthur, Isolde Woittiez, and Arie Kapteyn, 1990, "Labor Supply, Income Taxes, and Hours Restrictions in the Netherlands," Journal of Human Resources, 25(3), pp. 517-558.

Van Soest, Arthur, Marcel Das, and Xiaodong Gong, 2002, “A structural labour supply model with flexible preferences," Journal of Econometrics, 107, pp.345-374. 